\title{
Vacuolar organization in the nodule parenchyma is important for the functioning of pea root nodules
}

\author{
Marzena Sujkowska • Magdalena Górska-Czekaj • \\ Magdalena Bederska • Wojciech Borucki
}

Received: 11 October 2010 / Accepted: 20 July 2011 /Published online: 9 August 2011

(C) The Author(s) 2011. This article is published with open access at Springerlink.com

\begin{abstract}
Different models have been proposed to explain the operation of oxygen diffusion barrier in root nodules of leguminous plants. This barrier participates in protection of oxygen-sensitive nitrogenase, the key enzyme in nitrogen fixation, from inactivation. Details concerning structural and biochemical properties of the barrier are still lacking. Here, the properties of pea root nodule cortical cells were examined under normal conditions and after shoot removal. Microscopic observations, including neutral red staining and epifluorescence investigations, showed that the inner and outer nodule parenchyma cells exhibit different patterns of the central vacuole development. In opposition to the inner part, the outer parenchyma cells exhibited vacuolar shrinkage and formed cell wall infoldings. Shoot removal induced vacuolar shrinkage and formation of infoldings in the inner parenchyma and uninfected cells of the symbiotic tissue, as well. It is postulated that cells which possess shrinking vacuoles are sensitive to the external osmotic pressure. The cells can give an additional resistance to oxygen diffusion by release of water to the intercellular spaces.

Immunolocalization studies proved higher expression of endo- $\beta-1,4$-glucanases within expanding cells of the outer cortex of pea nodules comparing with nodule endodermis or nodule parenchyma, so it is suggested that (1) endoglucanases are involved in growth related modifications of cell walls and (2) enlarged cells decrease nodule conductance to oxygen.
\end{abstract}

M. Sujkowska $\cdot$ M. Górska-Czekaj · M. Bederska

W. Borucki $(\bowtie)$

Department of Botany,

Warsaw University of Life Sciences-SGGW,

Nowoursynowska 159,

Warsaw 02-776, Poland

e-mail: wojciech_borucki@sggw.pl
Keywords Endo- $\beta$-1,4-glucanase $\cdot$ Immunolocalization . Nodule parenchyma Pisum sativum $\cdot$ Root nodule .

Central vacuole $\cdot$ Neutral red

\section{Introduction}

Root nodules of leguminous plants are unique organs that fix atmospheric nitrogen into ammonia. Nitrogenase is a key enzyme responsible for nitrogen fixation. This enzyme, very sensitive to oxygen, is located in bacteroids which represent special kind of rhizobia cells (Hunt and Layzell 1993). Bacteroids occupy so called infected cells in the nodule interior. An appropriate modification of the respiratory chain of the bacteroids allows them respire efficiently at a very low free oxygen concentration protecting their nitrogenase from inactivation (e.g. Bergersen and Turner 1993).

Two factors are considered to be responsible for the maintenance of low oxygen concentration around bacteroids: (1) oxygen diffusion barrier operating in the nodule cortex (Tjepkema and Yocum 1974) and (2) leghemoglobin protein with high affinity to oxygen located in the cytosol of infected cells (Appleby 1984). Some authors postulate that respiratory consumption of oxygen by cells at nodule periphery must be considered as the third factor in the control of oxygen concentration within nodule interior (Dalton et al. 1998).

Oxygen diffusion to the root nodule interior is promoted by air filled intercellular spaces between cells of the peripheral tissues because water or protein occluded spaces give high resistance to gas diffusion (Minchin 1997). Thus, regulation of the volume of air filled intercellular spaces appears to be a key factor in nodule functioning. On the other hand, large leghemoglobin content in the root nodule 
facilitates high rate of $\mathrm{O}_{2}$-flux at low free oxygen to bacteroids (Wittenberg et al. 1974). But it must be underlined that in spite of high leghemoglobin concentration, oxygen pool fixed by this protein can support the respiration of bacteroids only by seconds so steady state delivery of oxygen to the nodule interior is necessary to support the respiratory activity of bacteroids (Walsh 1995). Ott et al. (2005) underline that leghemoglobins (1) increase the flux of oxygen to sites of respiration and (2) help to establish very low free-oxygen concentrations within nodules.

Different treatments can change nodule permeability to oxygen diffusion thus affect nodule metabolism. Example treatments include (1) nodule exposition to non-ambient $\mathrm{O}_{2}$ concentration or (2) argon:oxygen atmosphere, and (3) stem girdling, detopping or application of fertilizer (for detailes see Wei and Layzell 2006). There are several concepts on mechanism(s) regulating the nodule's permeability to oxygen diffusion in response to the treatments. Most concepts involve changes in the volume of gaseous intercellular spaces in the nodule parenchyma. One concept postulates that the degree of the occlusion of intercellular spaces with glycoproteins (James et al. 1991) or water (Streeter 1992; Purcell and Sinclair 1994) may influence oxygen diffusion across nodule cortex. Another hypothesis for the regulation of nodule permeability is that oxygen consumption by respiratory activity in the endodermis or nodule parenchyma is a key component of the diffusion barrier (Dalton et al. 1998).

The aim of this study was to characterize the development of cortical tissues of pea root nodules with special focus on the nodule parenchyma. Most observations, which touched the problem of nodule resistance to oxygen diffusion, were curried out on soybean root nodules, which are of determinate type. Our investigations were done on pea root nodules representing indeterminate type of nodule with its persistent meristem and characteristic zonation. Cytological and cytochemical observations showed that nodule parenchyma of pea nodules is composed of two different cell types. One adjacent to the infected cells (inner parenchyma) shares common properties to the uninfected cells of the bacteroidal tissue but the other one (outer parenchyma) posses shrinking vacuoles, diluted cytoplasm and infolded radial cell walls as a result of turgor collapse. The importance of cell vacuolation to the functioning of the outer parenchyma cells and probably the whole nodule is underlined by shrinkage of vacuoles within inner parenchyma and uninfected cells observed after shoot removal. It is proposed that the fate of cell vacuolation within the outer parenchyma of pea nodules is important for regulation of oxygen diffusion to the nodule interior.

It is also postulated that cell wall infoldings together with a material of RER origin between them may be involved in the functioning of gas diffusion barrier by regulation of the volume of the intercellular spaces.

\section{Material and methods}

\subsection{Plant culture}

Pea (Pisum sativum L. cv. Szesciotygodniowy) seeds were surface-sterilized in 70\% ethanol $(2 \mathrm{~min})$ and $5 \%$ sodium hypochloride ( $5 \mathrm{~min}$ ), rinsed four times in sterile water and placed on wet, sterile filter paper and germinated. When radicles had reached $2 \mathrm{~cm}$, four seedlings were sown aseptically in each 21 pot filled with perlite and inoculated with Rhizobium leguminosarum bv. viciae 248 (wild type, effective). Plants were grown in a growing room (day/night temperature of $22 / 18^{\circ} \mathrm{C}$, day/night photoperiod of $14 \mathrm{~h} /$ $10 \mathrm{~h}, 350-400 \mu \mathrm{mol} \mathrm{m} \mathrm{m}^{-2} \mathrm{~s}^{-1}$ of PAR). All plants were given nitrogen free medium (Fahraeus 1957) twice a week and sterile water as required.

\subsection{Experimental procedures}

After 2 weeks post inoculation nodules were collected and processed for investigations.

\subsection{Nodule anatomy and cytology}

Development of the nodule cortex was investigated by light and electron microscopy. Nodules (ca. $2 \mathrm{~mm}$ long) were collected separately from control uncut or decapitated plants. In case of treated plants nodules were collected $4 \mathrm{~h}$ after shoot removal. Hand sections of 2 weeks old nodules were fixed according to Karnovsky (1965). The sections were then postfixed in $1 \% \mathrm{OsO}_{4}$ for $3 \mathrm{~h}$, dehydrated in a graded ethanol series and acetone and finally embedded in glycid ether 100 epoxy resin (SERVA) equivalent to the former Epon 812. Blocks were sectioned using microtomes (Jung RM 2065 and Ultracut UCT, Leica). Semithin sections were stained for $1 \mathrm{~min}$ with a mixture of $1 \%(\mathrm{w} / \mathrm{v})$ methylene blue and $1 \%(\mathrm{w} / \mathrm{v})$ azure A and examined under light microscope (Axioskop, Zeiss, Germany). Thin sections were collected on copper grids and stained with uranyl acetate followed by lead citrate for $5 \mathrm{~min}$ and examined under transmission electron microscope (JEM 1220, JEOL, Japan).

\subsection{Uptake of neutral red by the vacuoles of pea root} nodules

In order to visualize vacuoles in the nodule cortex and symbiotic tissue of pea root nodules we used neutral red (NR) staining (Dubrovsky et al. 2006). Attached nodules 
were stained with NR $(4 \mu \mathrm{M}$ in $0,1 \mathrm{MK}$-phosphate buffer, $\mathrm{pH}$ 8) for $4 \mathrm{~h}$. NR at $\mathrm{pH} 8.0$ was used to minimalize staining of the cell walls (Dubrovsky et al. 2006). This was a good staining condition that produced high fluorescence intensity and allowed visualization of vacuoles in different nodule zones and cortex. Longitudinal hand sections through the nodules were observed under Olympus-Provis epifluorescence microscope equipped with $\mathrm{D} / \mathrm{F} / \mathrm{TR}$ triple-band filter cube with excitation filter/barrier filter (nm) 390-410/490-505, 560-585/450$475,515-545 / 605-680$, respectively.

\subsection{Succinate dehydrogenase assay}

Localization of succinate dehydrogenase (SDH) activity was performed according to Chauhan and Lal (1982) method. Fresh longitudinal, hand-made nodule sections were transferred to incubation medium containing $0,5 \mathrm{mg} /$ $\mathrm{ml}$ of nitro-blue tetrazolium (NBT) in $0.05 \mathrm{M}$ phosphate buffer ( $\mathrm{pH}$ 7.6), supplemented with $0.05 \mathrm{M} \mathrm{Na-succinate}$ for $30 \mathrm{~min}$ at $37^{\circ} \mathrm{C}$, then washed for $10 \mathrm{~min}$ in two changes of pure buffer, mounted in $10 \%(\mathrm{v} / \mathrm{v})$ glycerol and observed under bright field technique. Succinate was used in this assay as a substrate and NBT as an electron acceptor. The sites of SDH activity (mitochondria and bacteroids) appeared deep blue. Control treatments included (1) incubation in a medium without substrate, (2) incubation after heat inactivation at $80^{\circ} \mathrm{C}$ for $1 \mathrm{~h}$ and (3) preincubation with $10 \mathrm{mM}$ iodoacetate for $30 \mathrm{~min}$. Ommision of the substrate and heat inactivation substantially reduced the intensity of the reaction. Preincubation in the presence of iodoacetate (SDH inhibitor) totally inhibited SDH activity (not shown).

\subsection{Localization of suberin and lignin}

Suberin and lignin staining on nodule sections was performed as described by Brundrett et al. (1988). Nodules were fixed according to Karnovsky (1965), embedded in BMM (Gubler 1989), sectioned at $2 \mu \mathrm{m}$ with a microtome (Jung RMM 2065), stained overnight in $0.1 \%(\mathrm{w} / \mathrm{v})$ berberine hemisulphate (Sigma) at room temperature and then rinsed several times with distilled water. For quenching of autofluorescence, sections were incubated in $0.1 \%$ toluidine blue staining solution for $30 \mathrm{~min}$ at room temperature. The sections were rinsed as above, transferred to a $0.1 \% \mathrm{FeCl}_{3}$ in $50 \%(\mathrm{v} / \mathrm{v})$ glycerin for $5-10 \mathrm{~min}$, mounted on microscope slides in the same solution and viewed under UV light (U-MNU narrow-band filter cube with excitation filter/barrier filter (nm) 360-370/>420, respectively).

The lignin in nodule endodermal cell walls was also visualized after phloroglucinol staining (Zhong et al. 2000).
Phloroglucinol interacts with the cinnamylaldehyde residues in lignin which results in a crimson color. Free-hand longitudinal sections of fresh 2 -week-old nodules were stained with phloroglucinol- $\mathrm{HCl}(2 \%$ [w/v] phloroglucinol in $36 \% \mathrm{HCl}$ ) and observed under bright field.

\subsection{Distribution of carboxyfluorescein across nodule cortex}

The apoplastic transport across nodule cortex was observed using the fluorescent dye 5(6)carboxyfluorescein (CF; Sigma). CF is a small hydrophilic molecule which is expected to be ionized in the apoplast (Kramer et al. 2007). Charged forms of CF do not cross the plasmalemma thus remain in the apoplast (Oparka 1991; Kramer et al. 2007). Nodulated roots of 2 weeks plants were rinsed in aerated nutrient solution ( $\mathrm{pH}$ 5.8) suplemented with $\mathrm{CF}$ (final concentration $10 \mu \mathrm{g} / 1 \mathrm{ml}$ ), at room temperature. After 4 or $24 \mathrm{~h}$ nodules were washed out and cut with a razor blade. Nodule sections were placed in $10 \%$ glycerol and observed under Olympus-Provis epifluorescence microscope equipped with $\mathrm{D} / \mathrm{F} / \mathrm{TR}$ triple-band filter cube.

\subsection{Immunolocalization of endo-ß-1,4-glucanases}

\subsubsection{Antibody for endo- $\beta$-1,4-glucanases immunolocalization}

Antibody against the endo- $\beta$-1,4-glucanase protein was raised in rabbit. A cDNA fragment was selected, which corresponded to EGL1 in elongating pea epicotyls induced by auxin (Wu et al. 1996). The sequence of EGL1 (L41046) is recorded in GenBank. EGL1 is similar to other plant EGases. EGL1 has $76 \%$ identity with an Arabidopsis EGase, about $60 \%$ identity with EGase associated with fruit ripening, but only $50 \%$ identity with those expressed in abscission zone (Wu et al. 1996). Antibody was generated in rabbit by immunizing with the peptide antigen CYFPKRIHHRGSSLP, sequence at the C terminus. Obtained antiserum was purified with the Protein A Antibody Purification Kit (Sigma).

\subsubsection{Plant material and western blot analysis}

Nodules were collected 18 days post inoculation (dpi) for the investigation. Auxin treated pea epicotyls (see below) and uninfected pea roots (14 dpi) from control plants were also taken. For isolation of wall-associated proteins, equal fresh weights of pea uninfected roots, etiolated epicotyls or root nodules were ground to a powder in liquid nitrogen with mortar. Proteins were extracted with a buffer $(2 \mathrm{ml} / \mathrm{g}$ fresh weight) containing $20 \mathrm{mM}$ Tris- $\mathrm{HCl}(\mathrm{pH} 8.0), 3 \mathrm{mM}$ EDTA, $0.5 \mathrm{M} \mathrm{NaCl} \mathrm{pH}$ 8. The mixture was homogenized at $4^{\circ} \mathrm{C}$ for $2 \mathrm{~h}$ and then centrifuged at $14000 \mathrm{rpm}$ for $5 \mathrm{~min}$. Proteins were precipitated by adding cold acetone to a final 
concentration of $80 \%(\mathrm{v} / \mathrm{v})$. Protein content was measured in extracts according to Bradford (1976).

One-dimensional SDS-PAGE was performed according to the method of Laemmli (1970) using 10\% (v/v) polyacrylamide gels. After electrophoresis, proteins were transferred electrophoretically to nitrocellulose membranes. Membranes were then blocked with TBS (100 mM, $150 \mathrm{mM} \mathrm{NaCl}$ ) containing $5 \%$ skim milk for $2 \mathrm{~h}$ at room temperature. Blocked membranes were incubated for $1 \mathrm{~h}$ with a 1:100 dilution of primary rabbit antibody followed by the addition of a 1:20000 dilution of secondary goat anti-rabbit antibody conjugated with alkaline phosphatase (Sigma). Alkaline phosphatase activity was detected using BCIP (5-bromo-4-chloro-3-indolyl phosphate) and NBT (nitro blue tetrazolium) according to Sambrook et al. (1989).

\subsubsection{Hormone treatments}

Etiolated 8-day old pea epicotyl segments $(6 \mathrm{~mm})$ were cut directly below the tip (Pauly et al. 2001) and incubated in $25 \mathrm{mM}$ potassium phosphate buffer ( $\mathrm{pH} 6.0$ ) containing $2 \%$ $(\mathrm{w} / \mathrm{v})$ sucrose for $3 \mathrm{~h}$ (Catalá et al. 2000) to deplete endogenous auxin and then incubated in the buffer supplemented with the synthetic auxin 2,4-D $(5 \mathrm{mM})$ for $24 \mathrm{~h}$ at $25^{\circ} \mathrm{C}$ in the dark with gentle agitation.

\subsubsection{Immunolocalization procedures for light (LM) and Transmission Electron Microscopy (TEM)}

Samples containing sections of nodules were collected 18 dpi. They were fixed in $4 \%$ paraformaldehyde on MSB buffer for $2 \mathrm{~h}$ at room temperature. Fixed samples were dehydrated in graded ethanol series and embedded in butylmethylmethacrylate resin (BMM) (Gubler 1989) for LM. Samples for immunogold labeling after dehydration in series of ethanol solution were embedded in LR White resin (VandenBosch et al. 1994) for TEM.

Material for epifluorescence observations was embedded in BMM and cut into semithin sections $(3 \mu \mathrm{m})$ using Leica RM2165 microtome. After resin removal with acetone sections were incubated in a blocking solution containing $5 \%$ skim milk powder in TBS for $1 \mathrm{~h}$ before an application of the primary rabbit antibody. The sections were washed in TBS with $0.05 \%$ Tween 20 and incubated for $90 \mathrm{~min}$ at room temperature in a dilution $(1: 30)$ of purified primary rabbit antibody against endo- $\beta$-1,4-glucanase supplemented with $1 \%$ skim milk before washing in TBS-Tween and application of a dilution (1:2000) of the secondary goat anti-rabbit antibody conjugated to Alexa Fluor 488 (Molecular Probes) for $1 \mathrm{~h}$. The sections were washed as describe above and stained with $0.1 \%$ toluidine blue for $10 \mathrm{~min}$ to minimize tissue autofluorescence. The sections were mounted in immuno-fluore mounting medium (ICN) and examined by fluorescent microscopy. Olympus-Provis epifluorescence microscope was equipped with a tripleband filter cube (D/F/TR-Olympus). This cube has a combination of band-pass excitation/barrier filters of 390 $410,490-505,560-585 / 450-475,515-545,605-680 \mathrm{~nm}$, respectively.

Material for transmission electron microscopy observations was embedded in LR White resin, cut into ultrathin sections $(70 \mathrm{~nm})$ and transferred to 150 -mesh nickel grids, previously coated with formvar. Girds were treated with blocking solution (3\% BSA in TBS) for $1 \mathrm{~h}$ at room temperature, washed in TBS-Tween buffer (TBS with $0.05 \%$ Tween) and incubated in a solution containing the primary antibody diluted $1: 10$ for $90 \mathrm{~min}$ at room temperature. Next, the sections were washed with TBS and incubated in the secondary goat anti-rabbit antibody (1:50) (Sigma) conjugated to 10-nm colloidal gold particles for $1 \mathrm{~h}$. Then, the sections were washed as described above and contrasted with $2 \%$ uranyl acetate for $1 \mathrm{~min}$, washed in distilled water and examined under transmission electron microscope (Morgagni 268D, FEI Company) equipped with the digital camera (Morada, SIS).

\section{Results}

3.1 Light and electron microscopy of nodule peripheral layers

The nodules of pea are of indeterminate type with characteristic zonation of the bacteroidal tissue (Fig. 1a) (see also Vasse et al. 1990; Guinel 2009). From the distal to proximal part of the nodule several zones can be distinguished like meristematic zone (not shown), early symbiotic zone, interzone and late symbiotic zone. On the other hand, nodule peripheral tissues can be divided (according to the nomenclature proposed by Hirsch (1992)), from the outside in, into: (1) outer cortex composed of large expanding cells, (2) nodule endodermis with tightly packed cells containing suberin lamella and (3) inner cortex interchangeably termed as nodule parenchyma (Figs. 1a and 2a). Additionally, the nodule parenchyma could be divided into the outer and inner parts on the base of their affinity toward methylene blue and azure A and the fate of their vacuolation. The outer parenchyma cells stained completely with the dyes and as a result no boundary between cytoplasm and central vacuole could be observed under light microscopy level. In case of the inner parenchyma cells their cytoplasm located adjacent to cell wall was easily distinguished from central vacuole (Fig. 1b).

Shrinkage of central vacuoles was observed in 1-3 cell layers of the outer parenchyma located opposite to the early 

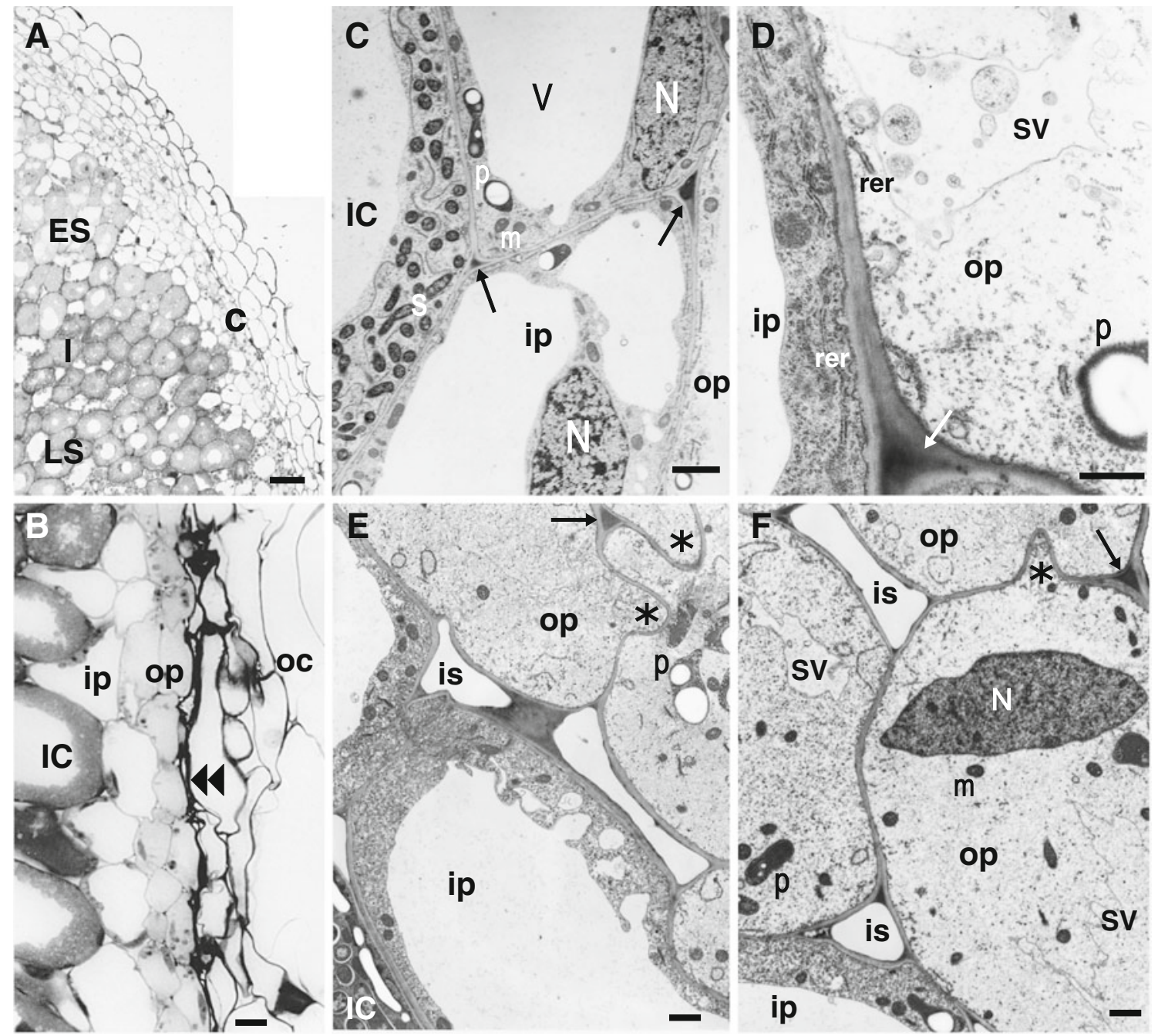

Fig. 1 Light and electron micrographs of a 2-week-old pea root nodule structure of control plants. (a and b) Light micrographs. (a) Longitudinal section of pea root nodule with characteristic zonation of the symbiotic tissue. (b) Methylene blue staining of fully differentiating nodule cortex located opposite the late symbiotic zone shows that nodule parenchyma can be divided into the inner and outer parenchyma. Notice that in contrast to the inner parenchyma, the profiles of the outer parenchyma cells stain equally with methylene blue - they are grey under grey level mode. (c-f) Electron microscopy. (c and d) Undifferentiating parenchyma cells located opposite to the early symbiotic zone. Notice that the inner parenchyma cells can be distinguished from the outer parenchyma cells on the basis of their vacuolation. It is also worth mentioning that intercellular spaces are

symbiotic zone (Fig. 1c and d). The cells had diluted, expanding cytoplasm comparing with dense cytoplasm of the inner parenchyma cells. As a result of this expansion, organelle previously located close to the cell wall could be found in the cell interior. Concomitantly with the shrinkage of vacuoles, the radial cell walls formed infoldings (Fig. 1e and $\mathrm{f}$.

An opaque and amorphous material occluded intercellular spaces of the young nodule parenchyma located opposite to early symbiotic zone (Fig. 1c and d). Transition occluded. (e and f) Mature nodule parenchyma. Radial cell wall infoldings, shrinking vacuoles and diluted cytoplasm are characteristic features of the outer parenchyma cells. Notice also steady distribution of organelle within the outer parenchyma cells. Abbreviations: arrow-occluded intercellular spaces, c-cortex, $C V$-shrinking vacuole, double-arrowhead - nodule endodermis, I-interzone, icinfected cell of the late symbiotic zone, is-intercellular space, ip inner parenchyma, $o c$ - outer cortex, $o p$ - outer parenchyma, $L S$-late symbiotic zone, $m$-mitochondrium, $N$-nucleus, $p$-plastid, rerrough endoplasmic reticulum, $s$-symbiosome, star-folded radial cell wall (wall infolding), $V$-vacuole, $E S$ - early symbiotic zone. Bars: $\mathrm{A}=50 \mu \mathrm{m}, \mathrm{B}=10 \mu \mathrm{m}, \mathrm{C}=2 \mu \mathrm{m}, \mathrm{D}-\mathrm{F}=1 \mu \mathrm{m}$

from young to mature nodule parenchyma resulted in an appearance of translucent intercellular spaces but some of the spaces within outer parenchyma remained fully occluded (Figs. 1e and f, 2c).

Distinct suberin lamella was characteristic feature of the state-II nodule endodermis which developed opposite to the interzone (Fig. 2a and c). Mature outer parenchyma cells located adjacent to the nodule endodermis possessed numerous membraneous structures in the form of large RER circles (Fig. 2a and b) or small vesicles 

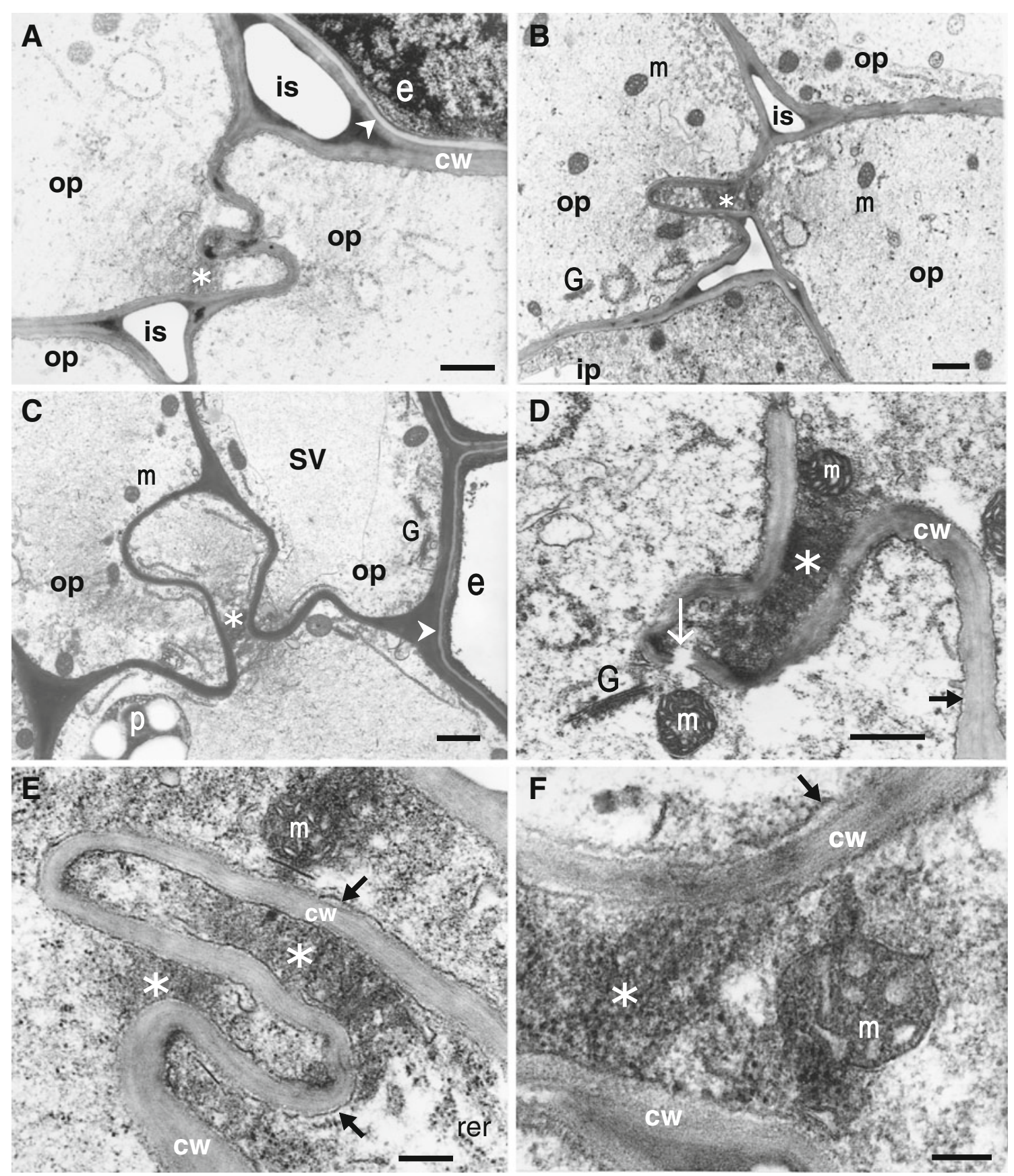

Fig. 2 Cell wall infoldings and cell wall discontinuity characterize the outer parenchyma cells of a 2 -week-old pea root nodules collected from control plants. (a) An electron-opaque material accumulates within cell wall infoldings. (b) Many membranous structures are located close to cell wall infoldings. (c) Two different cell wall infoldings are connected by a material deposited between them. (d) Digestive processes lead to the formation of cell wall discontinuity within cell wall infoldings. Mitochondria and Golgi bodies seem to cooperate in cell wall digestion. (e and f) A fine structure of the electron-opaque material located between folded cell walls. RER

profiles seem to participate in the formation of the material (e). Notice enlarged periplasmic space between bold plasma membrane and folded cell walls. Abbreviations: arrowhead - suberin lamellae, black arrow - bold plasma membrane, white arrow - cell wall discontinuity, $c w$ - cell wall, $C V$ - shrinking vacuole, $e$-nodule endodermis, $G$ Golgi body, is - intercellular space, ip - inner parenchyma, op - outer parenchyma, $m$ - mitochondrium, $p$ - plastid, rer-rough endoplasmic reticulum, $s$-symbiosome, star - electron-opaque material within cell wall infolding. Bars: $A-D=1 \mu \mathrm{m}, \mathrm{E}=0,5 \mu \mathrm{m}, \mathrm{F}=0,25 \mu \mathrm{m}$

dispersed in diluted cytoplasm (Fig. 2b). Mitochondria located around cell wall infoldings had electron-opaque matrix and dilated cristae (Fig. 2d-f). Cell wall infoldings

formed a niche where an electron-opaque (densely packed) material was accumulated. Figure $2 \mathrm{e}$ and $\mathrm{f}$ show fine structure of the material. Detailed electron microsco- 
py observation revealed that RER profiles were located in the vicinity of the material (Fig. 2e). Examples of the wall discontinuity between outer parenchyma cells were visible (Fig. 2d).

A periplasmic space (space between plasma membrane and cell wall) within infoldings was substantially expanded (Fig. 2f).

Shoot removal resulted in the shrinkage of vacuoles and turgor loss in both inner parenchyma cells (Fig. 3a-c) and uninfected cells of the late symbiotic zone (Fig. 3d). An appearance of infoldings in the inner parenchyma cells was also observed (Fig. 3b and c). RER profiles which formed large circles as well as numerous small vesicles were visible in the diluted cytoplasm of the inner parenchyma cells (Fig. 3a-d).

3.2 Visualization of the vacuolar system of pea root nodules by neutral red staining and epifluorescence microscopy

Nodules were stained with neutral red and examined under UV-microscopy. Neutral red accumulated in acidic vacuoles, and exhibited blue-green, pink or red fluorescence depending on the vacuolar content. Vacuolar content in both infected and uninfected cells of the early symbiotic tissue fluorescened blue-green or pink comparing with blue-green fluorescence of the adjacent nodule cortex

Fig. 3 Shrinkage of vacuoles and cell wall infoldings in the inner parenchyma of a 2-weekold pea root nodules observed after shoot removal. (a) Shrinking vacuoles and diluted cytoplasm in the inner parenchyma cells. RER rings are located close to the radial cell walls. (b) Cell wall infoldings are visible on radial cell walls. (c) Structure of the cell wall infoldings. Notice fine, fibrillar material (arrows) and numerous vesicles (arrowheads) visible in the vicinity of the infoldings. Stars indicate $r e r$ profiles which fill niches formed by folded cell walls. (d) Vacuole shrinkage is visible in uninfected cells after shoot removal. Abbreviations: arrowhead - small vesicles, $\mathrm{cw}$-cell wall, $C V$-shrinking vacuole, $G$ - Golgi body, $I C$ infected cell, is -intercellular space, ip - inner parenchyma, $o p$ - outer parenchyma, $m$ mitochondrium, $p$ - plastid, rer-rough endoplasmic reticulum, s-symbiosome, small arrows - fibrillar material, star-electron-opaque material within cell wall infolding, $U C$ uninfected cell. Bars: A and $\mathrm{B}=2 \mu \mathrm{m}, \mathrm{C}=0,5 \mu \mathrm{m}, \mathrm{D}=1 \mu \mathrm{m}$

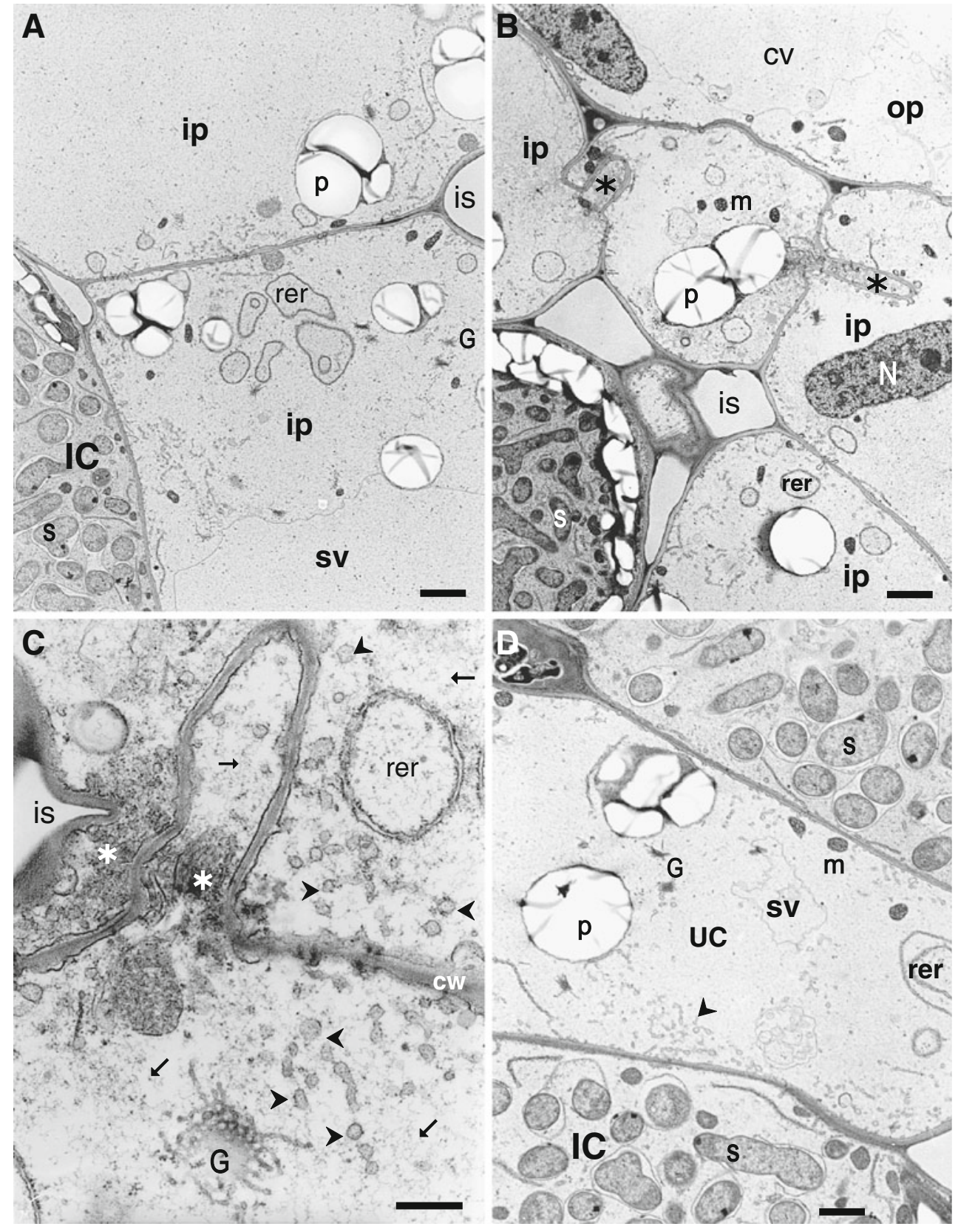


(Fig. 4a). Maturation of both the symbiotic tissue and nodule cortex resulted in an appearance of substantial differences in coloration of the vacuoles. Vacuolar content of the mature infected cells became nonfluorescened. More intensive red fluorescence of the vacuolar content was observed in uninfected cell of the late symbiotic zone and adjacent inner nodule parenchyma cells (Fig. 4a and b).

Mature cortical cells exhibited substantial differences in coloration of their vacuoles (Fig. 4b). The fluorescence of the vacuolar content of mature cortex cells changed from inside out, from red to blue-green, respectively (Fig. 4a and b). The most intensive red fluorescence was visible in the first cell layer of the inner parenchyma located adjacent to the proximal part of the mature symbiotic zone, and bluegreen fluorescence in the cortical cell layer located adjacent to the nodule endodermis (Fig. 4b). Shrinking vacuoles of the outer parenchyma cells fluorescened pink or blue-green (Fig. 4b). Vacuolar content of both, inner parenchyma cells and uninfected cells fluoresced red but there was no visible fluorescence of the vacuolar content of the infected cells (Fig. $4 \mathrm{a}$ and b). The lack of vacuolar staining of nodule endodermis may result from the impermeability of the cells to neutral red caused by their suberization and/or lignification (Fig. 4b).

Comparisons of the vacuolar size made on the basis of neutral red staining showed that vacuoles of the outer parenchyma cells were much smaller than vacuoles of the inner parenchyma (Fig. 4b).

Shoot removal resulted in a substantial reduction in the vacuolar volume in both cortical cells and uninfected cells of the late symbiotic zone. In addition, the intensity of fluorescence of the vacuolar content was much weaker comparing with control plants. Irregular shape of vacuoles in the inner parenchyma as well as in uninfected cells of the symbiotic tissue was observed (Fig. 4c).

3.3 Histochemical localization of succinate dehydrogenase activity on longitudinal sections

Respiration of pea root nodules was visualized by histochemical localization of succinate dehydrogenase (SDH) activity. SDH activity was very high at late symbiotic zone comparing with early symbiotic zone or nodule periphery (Fig. 5a). Within nodule periphery, the highest activity of
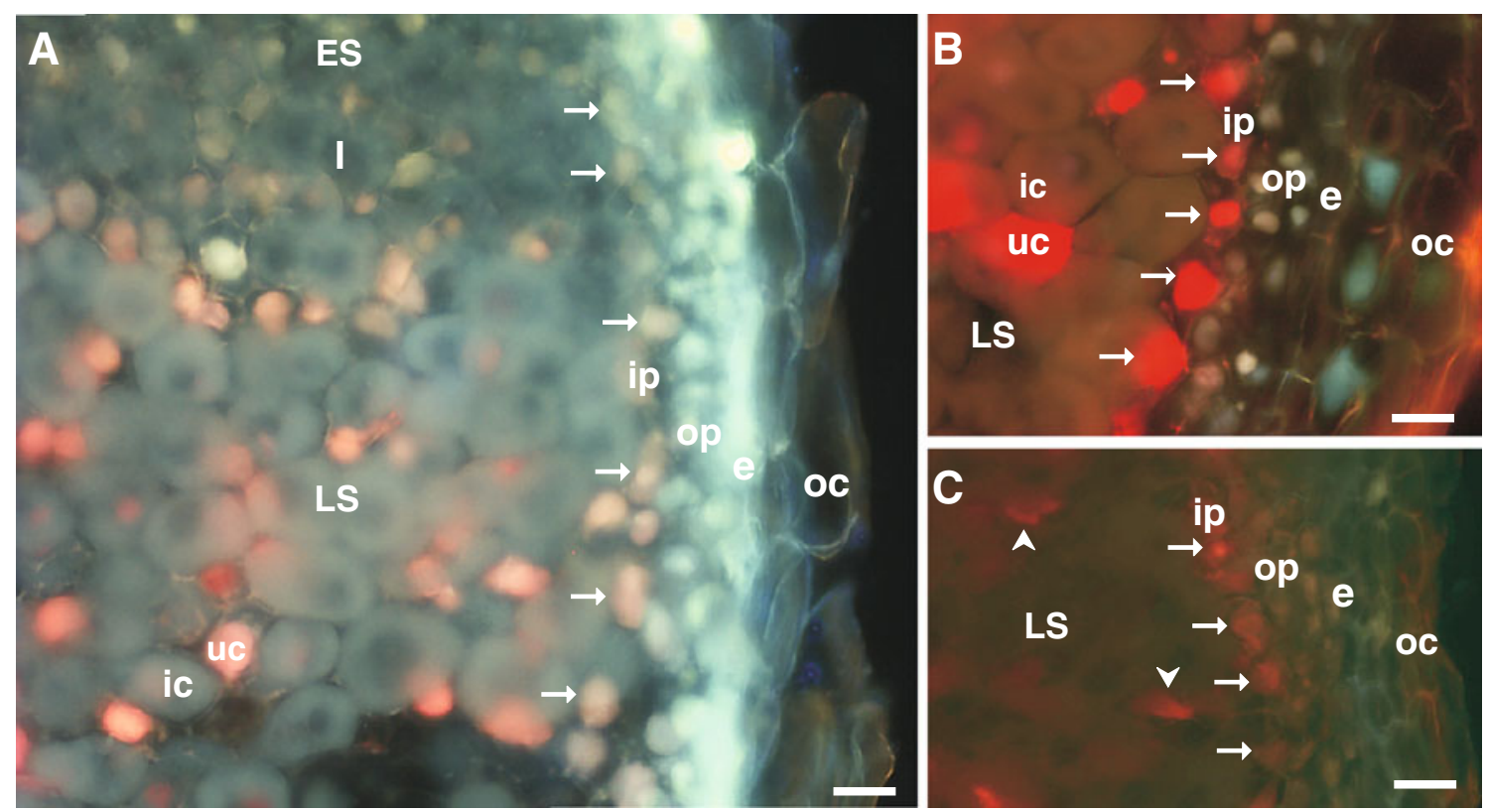

Fig. 4 Visualization of the vacuolar system of a 2-week-old pea root nodules by neutral red staining. (a) Green-blue fluorescing vacuoles in the nodule peripheral cell layers opposite to the early symbiotic zone are visible. Vacuoles within early symbiotic zone exhibit less intensive green-blue fluorescence. Notice, that vacuoles of the inner parenchyma cells adjacent to the late symbiotic zone show red fluorescence. The same characteristic inhabit vacuoles of uninfected cell of the late symbiotic zone. (b) Red-fluorescing vacuoles of the uninfected cells and inner parenchyma cells adjacent to the late symbiotic zone can be observed in mature part of pea root nodule of control plants. Notice the lack of vacuolar fluorescence of the infected cells of the late symbiotic zone. Fluorescence of the vacuolar content changes from red in the first cell layer of the inner parenchyma to blue-green in the nodule cortex. (c) Red-fluorescing vacuoles of the uninfected cells and inner parenchyma observed in mature part of pea root nodules $4 \mathrm{~h}$ after shoot removal. Notice irregular in shape, shrinking vacuoles of uninfected cells and inner parenchyma cells. Abbreviations: arrowvacuole of inner parenchyma cell, arrowhead-vacuole of uninfected cell, $e$-nodule endodermis, $I$-interzone, $i c$-infected cell of late symbiotic zone, is - intercellular space, ip - inner parenchyma, ocouter cortex, $o p$ - outer parenchyma, $L S$-late symbiotic zone, $u c$ uninfected cell of late symbiotic zone, $E S$ - early symbiotic zone. Bars $=25 \mu \mathrm{m}$ 
SDH was found at nodule parenchyma (Fig. $5 \mathrm{~b}$ and c). Some cells within nodule parenchyma exhibited very high SDH activity probably due to the abundance of mitochondria (Fig. 5c).

\subsection{Cell wall modifications within nodule cortex}

Cell wall modification of nodule endodermis was examined by berberine hemisulphate staining, an indicator of suberin and lignin. An intensive blue fluorescence of nodule endodermal walls located opposite to the interzone and late symbiotic zone (Fig. 6a and b) was an indicator of suberin and/or lignin. Nodule endodermal walls opposite to the early symbiotic zone exhibited only weak fluorescence (Fig. 6a)

Suberin and/or lignin were also detected in radial cell walls of the vascular endodermis (Fig. $6 \mathrm{c}$ and d). Tracheary elements showed intensive blue fluorescence probably as a result of their lignification (Fig. 6c).
The phloroglucinol-HCl staining technique showed that complete walls of the nodule endodermis are lignified but mainly outer tangential (Fig. 6e).

Infiltration of pea nodules with carboxyfluorescein (CF), an indicator of apoplastic transportation (Kramer et al. 2007), revealed almost complete exclusion of the dye by fully developed nodule endodermis located opposite to the late symbiotic zone (Fig. 6f). The dye accumulated mainly on the outer side of nodule endodermis and within outer cortex. Only small amounts of CF leaked through nodule endodermis to the outer parenchyma.

\subsection{Immunolocalization of EGL1 epitopes in pea root} nodules under fluorescence and electron microscopy

To determine the subcellular localization of EGL1 protein, a polyclonal antibody was raised in rabbit against $15 \mathrm{C}$ terminal amino acids of the protein. Immunoblotting with
Fig. 5 Histochemical localization of respiratory activity in pea root nodules. Blue staining is caused by reduction of NBT by succinate dehydrogenase. (a) Gradual increase in succinate dehydrogenase (SDH) activity from nodule meristem to the late symbiotic zone. (b) SDH activity is much higher within late symbiotic zone than in the nodule periphery. Notice higher SDH activity in nodule parenchyma comparing to nodule endodermis or cortex. (c) High level of SDH activity can be found in nodule parenchyma cells. Abbreviations: $e$-nodule endodermis, $I$-interzone, $i c$ infected cell of late symbiotic zone, $M$-nodule meristem, $L S$-late symbiotic zone, $n p$ nodule parenchyma, $o c$ - outer cortex, $u c$ - uninfected cell of late symbiotic zone, $E S$ - early symbiotic zone. Bars: $\mathrm{A}=$ $25 \mu \mathrm{m}, \mathrm{B}=50 \mu \mathrm{m}, \mathrm{C}=10 \mu \mathrm{m}$
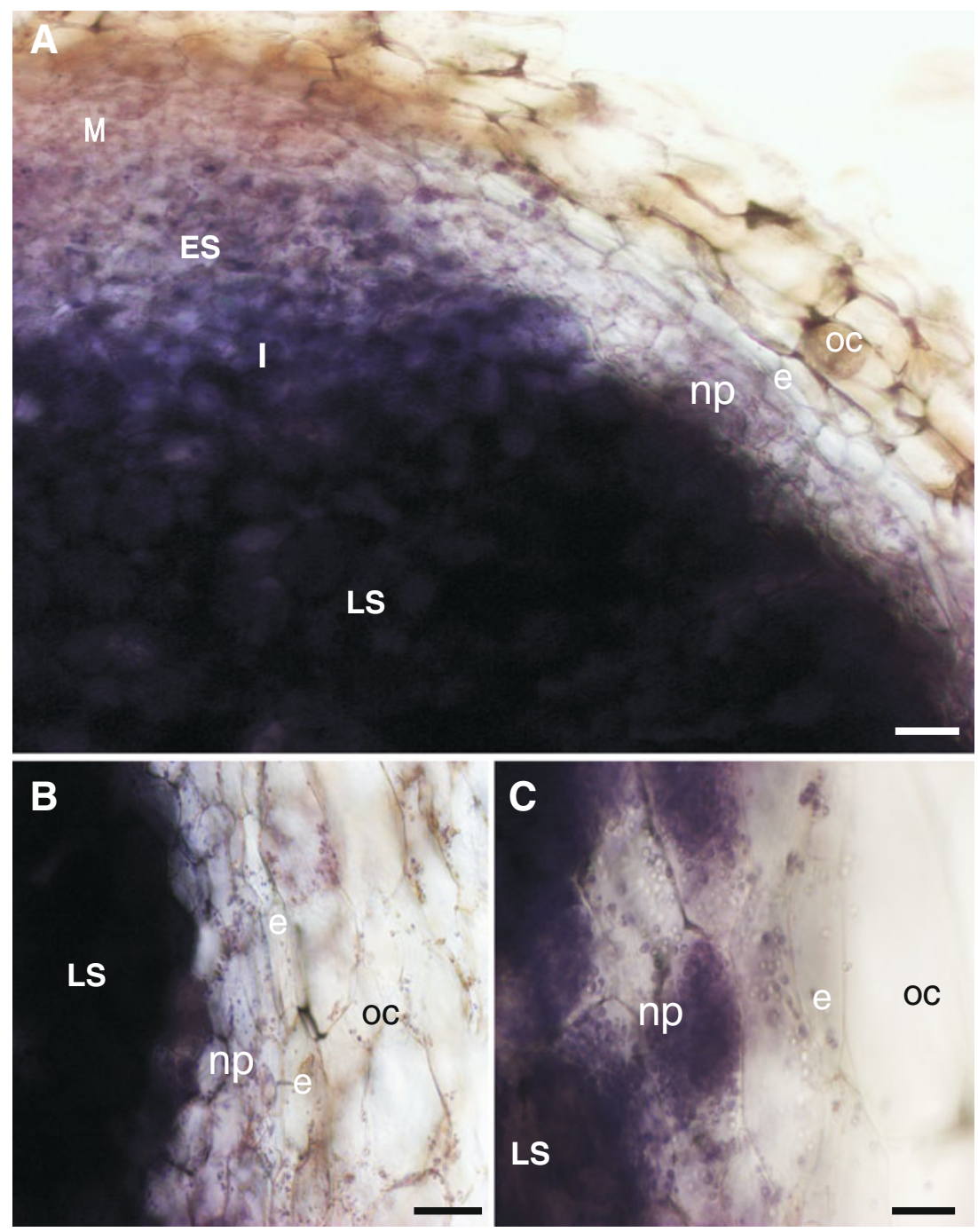

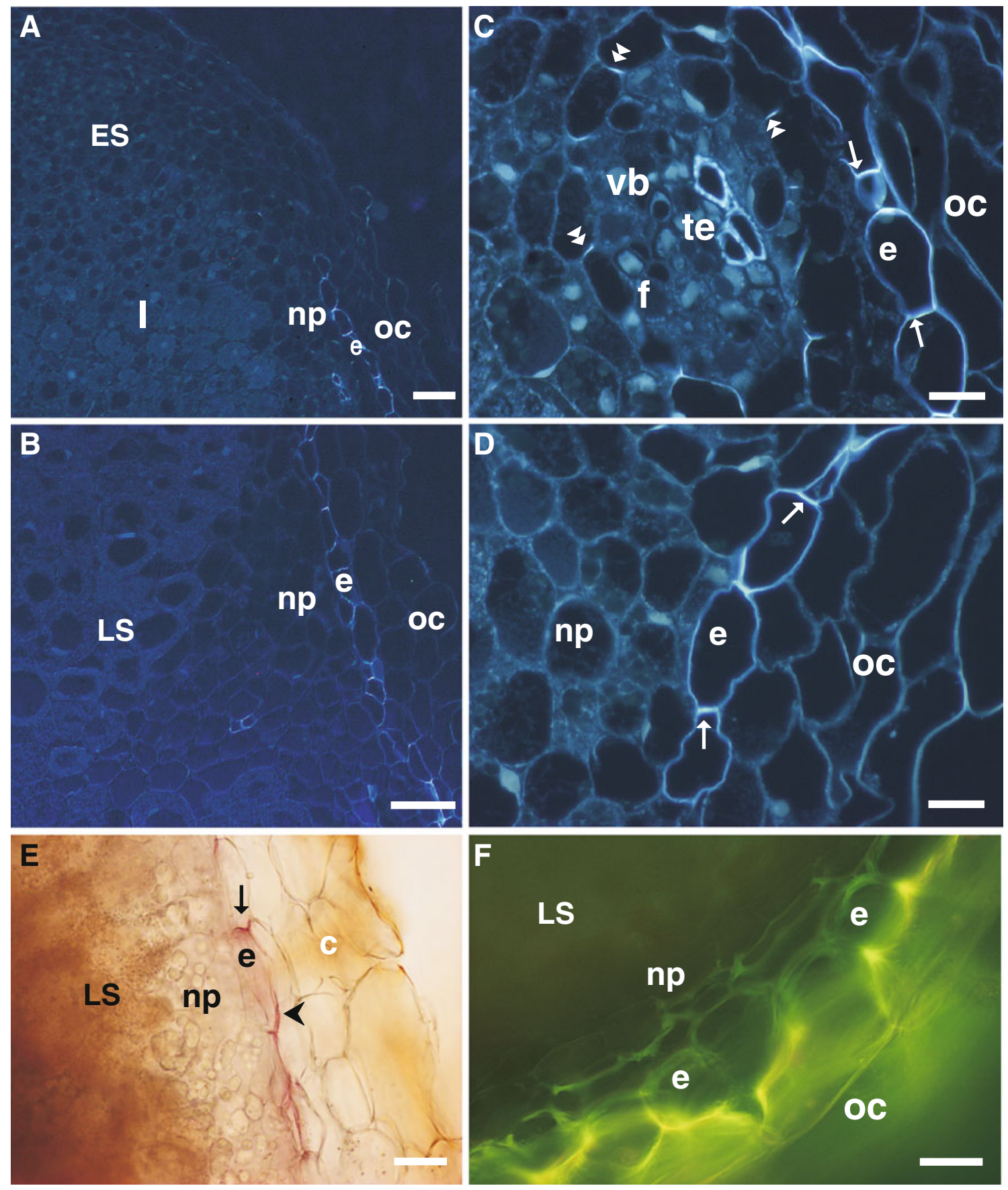

Fig. 6 (a and b) Longitudinal-sections through 2-week-old pea nodules, viewed under UV light irradiation. Sections stained with berberine hemisulphate. Blue fluorescened cell walls contain suberin and/or lignin. Blue fluorescence of nodule endodermal cell walls is detectable opposite to the interzone (a) and late symbiotic zone (b). (c and d) The fate of modification of nodule endodermal cell walls and vascular bundle endodermal cell walls (c - enlarged fragment of a). Notice intensive light-blue fluorescence of the radial walls (arrows) and only slightly less intensive fluorescence of tangential walls of nodule endodermis. Vascular endodermis shows intensive bright fluorescence of Casparian strips (double arrowheads). (e) Lignin was

the antibody demonstrated the presence of a single antigenic band migrating at approximately $60 \mathrm{kDa}$ in detected by phloroglucinol staining in cell wall of a 2-week-old nodule endodermis. Notice that lignification of the outer tangential walls of nodule endodermis is conspicuous. (f) Nodule endodermis $(e)$ is a barrier for apoplastic transportation of carboxyfluorescein. Notice that late symbiotic zone and nodule inner parenchyma were almost non-fluorescent. Abbreviations: arrows - intensive fluorescence of the radial cell walls of nodule endodermis, double arrowheadsCasparian strips of vascular endodermis, $e$-nodule endodermis, $f$ phloem, $I$-interzone, $L S$-late symbiotic zone, $n p$-nodule parenchyma, oc-outer cortex, $E S$ - early symbiotic zone, te-tracheary elements, $v b$ - vascular bundle. Bars: $\mathrm{A}$ and $\mathrm{B}=50 \mu \mathrm{m}, \mathrm{C}-\mathrm{F}=25 \mu \mathrm{m}$

etiolated epicotyls and root nodules but not in uninfected roots (Fig. 7). 
Fig. 7 Immunochemical detection of endo $\beta$-1,4-glucanase 1 (EGL 1) in uninfected roots $(R)$, etiolated epicotyls $(E P)$ and root nodules $(R N)$ of pea plants using polyclonal antibody after onedimensional electrophoresis, electro blotting to nitrocellulose sheets and treatment with goat anti-rabbit antibody conjugated to alkaline phosphatase. Size marker $(M)$ is indicated. Notice that antibody against EGL1 cross-reacted strongly with a protein isolated from nodule tissue and with a protein from pea epicotyls at $60 \mathrm{kDa}$

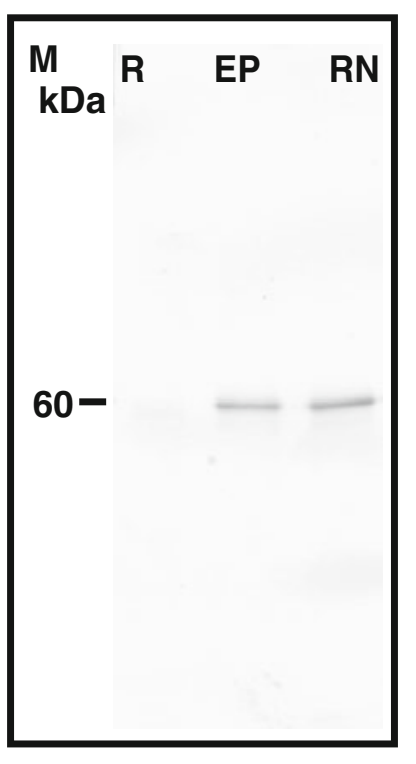

Fluorescence microscopy investigations proved that the EGL1 protein was localized in pea root nodules (Fig. 8) and found to be abundant in meristematic and early symbiotic zone (Fig. 8a) as well as in nodule outer cortex opposite to the late symbiotic zone (Fig. 8c).

Electron microscopy observations showed an intensive immunogold labeling of the meristematic cell cytoplasm and rather poor labeling of the cell walls (Fig. 8d). In case of early symbiotic zone which developed close to the nodule meristematic region, an intensive immunogold labeling was visible in infection thread walls and cell walls (Fig. 8e). The infection thread matrix and bacteria showed only background labeling (Fig. 8e).

In case of outer cortex located opposite to the late symbiotic zone, cell walls and the cytoplasm adjacent to the walls were labeled. Crevices visible within cell walls of the outer cortex cells were probably artificial and resulted from plant material fixation and/or embedding (Fig. 8f and g). The crevices were electron translucent and showed only background labeling.

\section{Discussion}

Several studies conducted on soybean, French bean, pea and alfalfa root nodules proved, that nodule cortex gives resistance to oxygen diffusion toward nodule interior (Tjepkema and Yocum 1974; Witty et al. 1987; Masepohl et al. 1993). The resistance to oxygen diffusion seems to be necessary to protect oxygen-sensitive nitrogenase against damage (Appleby 1984) and may be achieved by an occlusion of intercellular spaces with proteins and/or water. Intercellular spaces occluded with glycoproteins were recognized as an important factor responsible for low conductance of the nodule periphery to oxygen (James et al. 1991; Iannetta et al. 1993). Some authors postulated that also water filled intercellular spaces could give increased resistance to oxygen diffusion. The existence of water occlusions in the intercellular spaces of the nodule parenchyma was proved by electron microscopy observations (Weisbach et al. 1999). But operation of a rapid osmotic mechanism for adjustment of the nodule permeability to oxygen diffusion was questioned by Van Cauwenberghe et al. (1994), who observed no changes in the number and the cross-sectional area of gaseous intercellular spaces under $2 \mathrm{~h}$ exposure of soybean nodules to $80 \% \mathrm{O}_{2}$.

Observations were done on pea root nodules which represent the indeterminate growth pattern. Because of their zonation, such nodules give an extraordinary possibility to make direct comparisons between young and mature nodule tissues (Fig. 1).

Light and electron microscopy observations of nodule parenchyma located opposite to the early symbiotic zone of pea nodules revealed that intercellular spaces were occluded by a material (Fig. 1). This material probably corresponds to different proteins (VandenBosch et al. 1989; Nap and Bisseling 1990; VandenBosch et al. 1994) and isoflavones (Grandmaison and Ibrahim 1995) which were detected in intercellular occlusions of legume nodules. Proteins alone or together with flavonoids are recognized as a major factor regulating nodule resistance to oxygen diffusion (Minchin 1997).

Completely occluded intercellular spaces were observed within nodule parenchyma located opposite to the early symbiotic zone of pea nodules (Fig. 1c and d). This finding is in good accordance with earlier studies which demonstrated strong correlation between low level of free oxygen and the oneset of nitrogenase synthesis (James et al. 1997; Sheehy and Thornley 1998). It cannot be excluded that differentiation of rhizobia cells into bacteroids demands lowering of oxygen concentration within early symbiotic zone which is achieved by occlusion of intercellular spaces within nodule parenchyma. In case of nodule parenchyma located opposite to the late symbiotic zone, occluded or partially occluded intercellular spaces were visible within the outer nodule parenchyma. In opposition to the outer parenchyma, the inner parenchyma located opposite to the late symbiotic zone, possessed large intercellular spaces without any visible material. So, the distribution of the material depends on the maturity of the symbiotic tissue suggesting its importance to the functioning of the nodule parenchyma and the whole nodule as well.

Unstressed, functioning pea root nodules (Figs. 1 and 2) developed the outer parenchyma cells with characteristic vacuolar shrinkage. But, it should be underlined that observed vacuolar shrinkage is to a certain extend compensated by cytoplasm expansion so it has no profound 

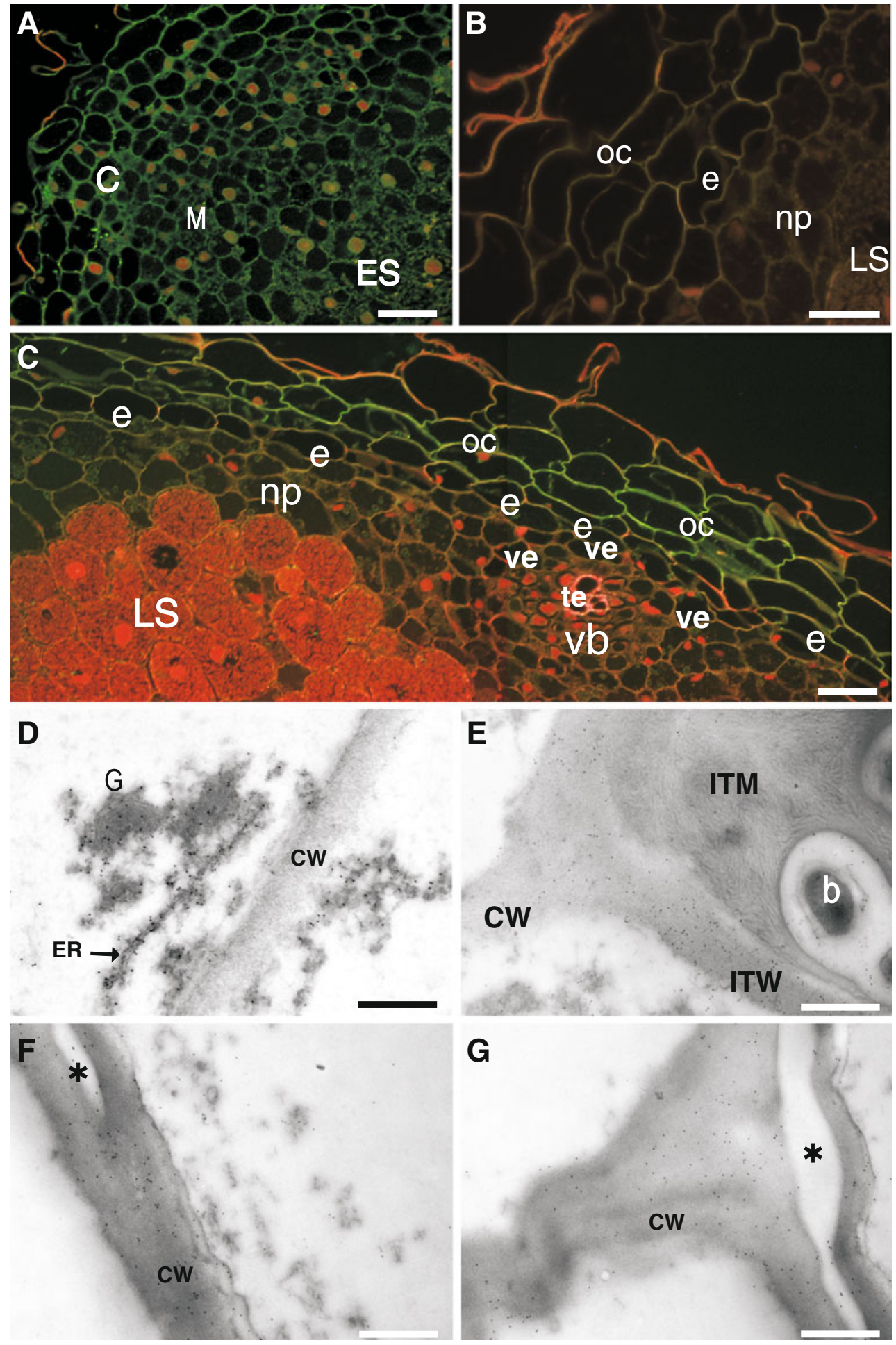

effect on the cell volume as in case of stomata cells (Raven 1987). Turgor loss manifested by vacuolar shrinkage of the cells resulted in formation of the radial wall infoldings. Such cells are probably very sensitive to even fine changes of the osmotic pressure in symplast and apoplast and can take up or release water, thus regulate the permeability of the diffusion barrier to oxygen. This finding is in good agreement with a hypothesis which involves an osmotic regulation of nodule cortex resistance to oxygen diffusion (Purcell and Sinclair 1994). Such regulation may involve rapid water fluxes across plasma membrane and tonoplast promoted by high expression of plasma membrane and tonoplast aquaporins found within inner cortex of soybean nodules (Fleurat-Lessard et al. 2005). 
4 Fig. 8 Immunolocalization of EGL1 protein in pea root nodules using polyclonal primary antibody is presented. (a-c) Immunolocalization of EGL1 protein on semithin longitudinal sections using secondary antibody conjugated to Alexa Fluor 488. Green fluorescence indicates the presence of EGL1 protein. (a) Distal part of pea root nodule. Green fluorescence of cells except nuclei, which exhibit red fluorescence, is visible. (b) Control immunostaining where preimmune serum was used instead of primary antibody. Notice that cells are almost non-fluorescent. (c) Proximal part of pea root nodule. Notice intense green fluorescence of cell walls of the outer cortex cells. Cell nuclei and cytoplasm of infected cells as well as tracheary elements exhibit red fluorescence. (d and e) Transmission electron microscopy immunolocalization of EGL1 protein on ultrathin sections using secondary antibody conjugated to gold particles $(10 \mathrm{~nm}$ in diameter). (d) Intense immunogold labeling of the cytoplasm of meristematic cell and ground labeling of its cell wall is shown. (e) Immunogold labeling of cell wall and infection thread in early symbiotic zone is presented. Notice that the cell wall and the infection thread wall are intensively labeled. The infection thread matrix shows only background labeling. (f and $\mathbf{g}$ ) Immunogold labeling of cell walls within outer cortex. Crevice-like structures in cell walls are artificial. Abbreviations: $b$ - bacterium inside infection thread, $c$ - cortex covering nodule meristem, $\mathrm{cw}$ - cell wall, $e$-nodule endodermis, $E R$ endoplasmic reticulum, $G$ - Golgi body, ITM - infection thread matrix, $I T W$-infection thread wall, $n p$-nodule parenchyma, oc-outer cortex, $v b$ - vascular bundle, $M$-nodule meristem, $L S$-late symbiotic zone, star - crevice like structure, te - tracheary elements, $V B$ vascular bundle, ve - vascular endodermis, $E S$ - early symbiotic zone. Bars: A-C $=50 \mu \mathrm{m}, \mathrm{D}-\mathrm{F}=0,5 \mu \mathrm{m}$

An appearance of new cells with shrinking vacuoles in the inner parenchyma and uninfected cells of the symbiotic tissue (Fig. 3) as a response to shoot removal, suggests that (1) shrinkage of vacuoles is an important factor in regulation of nodule conductance to oxygen diffusion and (2) an enhancement in the resistance to oxygen diffusion to prevent nitrogenase from inactivation is realized by cell turgor collapse.

Radial wall infoldings, together with an electron-opaque material between the infoldings, are major structural features of the outer parenchyma cells. On the other hand, an association of the material with RER cysternae, mitochondria and Golgi bodies suggests an activity of the infoldings in regulation of $\mathrm{O}_{2}$ entry into nodules. This suggestion is supported by the fact that an electron-opaque material seems to keep the structure of infoldings making them steeper. So, it is probable that cell wall infoldings and material accumulated between them, together with associated organella form a special apparatus important for the functioning of the outer parenchyma. Unusual properties of the infoldings are also underlined by cell wall discontinuities often observed within or close to them. The discontinuities may result from mechanical tensions and/or digestive processes. This observation also suggests a complexity of both, the outer parenchyma structure and functioning.

An importance of cell vacuolation within nodule symbiotic tissue and cortical cell layers was proved by vacuolar staining with neutral red, a vital $\mathrm{pH}$ indicator, and epifluorescence observations (Fig. 4). The specificity of the NR technique for acidotropic staining of vacuoles has been proved. Unprotonated form of neutral red easily crosses the plasma membrane and tonoplast. The dye in its protonated form does not penetrate membranes and is trapped in acidic compartments like plant vacuoles (e.g. Oparka 1991). Thus, the lack of fluorescence over the vacuoles in mature infected cells indicates that the vacuoles do not represent acidic compartments. But Fedorova and Brown (2007) observed under bright field technique slightly pink vacuoles in mature infected cells after neutral red staining. The discrepancies between both findings may result from the use of different neutral red staining procedures. In particular, in this study attached nodules were stained instead of nodule sections used by Fedorova and Brown (2007).

Red fluorescence over vacuoles in uninfected cells as well as inner parenchyma cells neighboring infected cells observed in pea nodules suggests common acidic properties of the vacuolar content of the cells. On the base of this finding functional similarity between both cell types can be expected. Newcomb et al. (1989) also proved functional similarity between the uninfected cells of the bacteroidal tissue and the cells of the inner cortex (nodule parenchyma) with respect to ureide production in determinate nodules.

On the other hand, neutral red staining revealed distinct differences in the level of vacuolation as well as vacuolar acidity and/or vacuolar content within pea nodule periphery. The diversity in composition of vacuolar content may reflect different metabolic properties and functions of particular cell layers which form nodule cortex.

Neutral red staining also supported observations done under electron microscopy which showed shrinkage of vacuoles in the outer parenchyma as well as in inner parenchyma and uninfected cells after shoot removal. It emphasized an importance of cell vacuolation to the nodule functioning under stress conditions. So, the level of cell vacuolation and properties of vacuoles may be a very important factors involved in an adjustment of nodule conductance to oxygen.

Mathematical modeling revealed that oxygen regulation could occur within infected cells. For instance, model proposed by Bergersen (1994) allows high respiratory activity of mitochondria within infected cells. Our observations indicate that respiratory activity (showed as SDH activity) was much higher in late symbiotic zone than in adjacent nodule periphery (Fig. 5), so it is possible that respiratory $\mathrm{O}_{2}$ consumption by mitochondria and bacteroids of the tissue is important in protection of dinitrogenase activity against oxidative damage. This suggestion is in accordance with the findings of Gardiol et al. (1987) who demonstrated that SDH activity is essential for proper bacteroid differentiation. Also, they showed that a mutant 
lacking SDH activity had much lower rate of oxygen consumption in free-living cultures than did the wild type.

Because some nodule parenchyma cells exhibited high level of SDH activity (Fig. 5), it cannot be excluded that respiratory activity of nodule parenchyma has also an effect onto lowering of oxygen concentration within symbiotic tissue, as well. The observations presented here regarding SDH activity support earlier suggestions (Minchin et al. 1992; Dalton et al. 1998) that oxygen diffusion barrier contains a respiratory component located in the nodule periphery.

Additional resistance to the oxygen diffusion across the nodule cortex can be given by the nodule endodermis (Witty et al. 1987, Hartmann et al. 2002). In case of pea, nodule endodermal cells, localized opposite to the late symbiotic zone, were surrounded by suberin lamellae (Fig. 2). Apart from suberin, nodule endodermal cell walls of pea contained lignins (Fig. 6). But according to some authors, suberized barriers seem to be more effective in restriction of oxygen diffusion than lignified (De Simone et al. 2003).

Nodule endodermis is also a good physical barrier for diffusion of carboxyfluorescein, the apoplastic dye (Fig. 6e). Because only small amounts of the dye were detected in the outer parenchyma and never reached symbiotic tissue it is suggested that endodermal cells are rather tightly packed with only minorous free space for diffusion of small molecules. Such properties of the endodermal cell layer indicate that endodermis is predestined to give some resistance toward diffusion of oxygen across cortex of pea nodules. Experiments with the use of a membrane impermeant dye (lucifer yellow) supplied under a mild vacuum, showed that the dye infiltrated through nodule endodermis into the inner cortex (Brown and Walsh, 1996). The authors concluded that the nodule endodermis is unlikely to be a significant barrier to oxygen diffusion.

Finally, EGases were localized immunocytochemically in pea root nodules (Fig. 8) to determine their influence on the development of nodule cortex. The antibody (antiEGL1 IgG) used in this study was monospecific as it recognized single band in western blots of wall associated proteins from the host extracts of pea epicotyls or nodules. What is more, the pre-immune serum used in identical western-blot labelling experiments did not produce any cross-reacting signal (data not shown). Higher expression of glucanases was found in expanding cells and their role in cell wall polysaccharide assembly or rearrangement was suggested (Brummell et al. 1997). Experiments conducted on pea by $\mathrm{Wu}$ et al. (1996) showed expression of EGL1 gene at the highest level in etiolated epicotyls, but also in stems, leaves, flowers, pods and roots. The continuous and high expression of EGases found in the outer cortex cells (Fig. 8c), which undergo a substantial enlargement, is conspicuous. It suggests an involvement of these enzymes in cell enlargement which may have an impact on the functioning of pea nodules. It was postulated that cell expansion can decrease nodule conductance to oxygen (De Lorenzo et al. 1993; Serraj et al. 1995). So the outer cortex cells of pea nodules are predestined to take part in regulation of nodule conductance to oxygen as the cells substantially enlarge during development. Additionally, endoglucanases could keep cell walls extensible and enable outer cortex cells to change their shape in response to soil conditions.

To conclude, the findings in this study indicate that the fate of vacuolation is important for the functioning of the outer parenchyma of pea root nodules. Outer parenchyma cells undergo unusual differentiation processes including the shrinkage of their vacuoles with simultaneous cytoplasm expansion and formation of radial wall infoldings. Such cells might be very sensitive to the external osmotic pressure and release or uptake water thus regulating permeability of intercellular spaces to oxygen. The importance of these cells in nodule functioning is emphasized by the fact that shrinkage of vacuoles was also observed in the inner parenchyma cells as well as uninfected cells of the symbiotic tissue after shoot removal.

Radial wall infoldings, together with densely packed material of RER origin around them, form an apparatus which may be involved in regulation of the volume of intercellular spaces within nodule parenchyma.

To the authors knowledge this is the first report which shows different properties of the vacuoles across nodule cortex of pea nodules after neutral red staining and subsequent epifluorescence observations. So different functions of particular cortical cell layers can be expected.

It was also proved that in case of indeterminate nodules, inner parenchyma cells and uninfected cells of the symbiotic tissue share common properties in terms of vacuolar acidity.

In addition, the current study demonstrates that endoglucanases are important for a substantial cell enlargement during differentiation of the outer cortex. Cell enlargement within outer cortex may be responsible for regulation of nodule conductance to oxygen.

Acknowledgements The authors wish to thank Ewa Znojek for technical assistance.

Open Access This article is distributed under the terms of the Creative Commons Attribution Noncommercial License which permits any noncommercial use, distribution, and reproduction in any medium, provided the original author(s) and source are credited

\section{References}

Appleby CA (1984) Leghemoglobin and Rhizobium respiration. Ann Rev Plant Physiol 35:443-478

Bergersen FJ (1994) Distribution of $\mathrm{O}_{2}$ within infected cells of soybean root nodules: a new simulation. Protoplasma $183: 49-61$ 
Bergersen FJ, Turner GL (1993) Effects of concentration of substrates supplied to $\mathrm{N}_{2}$ fixing soybean bacteroids in flow chamber reaction. Proc R Soc London Ser B 251:103-109

Bradford MM (1976) A rapid and sensitive method for the quantitation of microgram quantities of protein utilizing the principle of protein-dye binding. Anal Biochem 72:248-254

Brown SM, Walsh KB (1996) Anatomy of the legume nodule cortex: species survey of suberisation and intercellular glycoprotein. Aust J Plant Physiol 23:211-215

Brummell DA, Bird CR, Schuch W, Bennett AB (1997) An endo-1,4$\beta$-glucanase expressed at high levels in rapidly expanding tissues. Plant Mol Biol 33:87-95

Brundrett MC, Enstone DE, Peterson CA (1988) A berberine-aniline blue fluorescent staining procedure for suberin, lignin, and callose in plant tissue. Protoplasma 146:133-142

Catalá C, Rose JKC, Bennett AB (2000) Auxin-regulated genes encoding cell wall-modifying proteins are expressed during early tomato fruit growth. Plant Physiol 122:527-534

Chauhan E, Lal M (1982) Localization of some hydrolases and succinate dehydrogenase in the sporophyte gametophyte junction in Physcomitrium cyathicarpum Mitt. Ann Bot 50:763-769

Dalton DA, Joyner SL, Becana M, Iturbe-Ormaetxe I, Chatfield JM (1998) Antioxidant defenses in the peripheral cell layers of legume root nodules. Plant Physiol 116:37-43

De Lorenzo C, Ianetta PPM, Fernandez-Pascual M, James EK, Lucas MM, Sprent JI, Witty JF, Minchin FR, de Felipe MR (1993) Oxygen diffusion in lupin nodules II. Mechanisms of diffusion barrier operation. J Exp Bot 44:1469-1474

De Simone O, Haase K, Müller E, Junk WJ, Hartmann K, Schreiber L (2003) Apoplastic barriers and oxygen transport properties of hypodermal cell walls in roots from four amazonian tree species. Plant Physiol 132:206-217

Dubrovsky JG, Guttenberger M, Saralegui A, Napsucialy-Mendivil S, Voigt B, Baluška F, Menzel D (2006) Neutral red as a probe for confocal laser-scanning microscopy studies of plant roots. Ann Bot 97:1127-1138

Fahraeus G (1957) The infection of clover root hairs by nodule bacteria studied by a single glass slide technique. J Gen Microbiol 16:374-381

Fedorova EE, Brown S (2007) Cytochemistry of proteolytic activity and $\mathrm{pH}$ status of vacuoles in Medicago truncatula root nodules. Rus J Plant Physiol 54:25-31

Fleurat-Lessard P, Michonneau P, Maeshima M, Drevon J-J, Serraj R (2005) The distribution of aquaporin subtypes (PIP1, PIP2 and $\gamma$ TIP) is tissue dependent in soybean (Glycine max) root nodules. Ann Bot 96:457-460

Gardiol AE, Truchet GL, Dazzo FB (1987) Requirement of succinate dehydrogenase activity for symbiotic bacteroid differentiation of Rhizobium meliloti in alfalfa nodules. Appl Envir Microbiol 53:1947-1950

Grandmaison J, Ibrahim RK (1995) Ultrastructural localisation of diprenylated isoflavone in Rhizobium lupini-Lupinus albus symbiotic association. J Exp Bot 46:231-237

Gubler F (1989) Immunofluorescened localization of microtubules in plant root tips embedded in butyl-methyl methacrylate. Cell Biol Int Rep 13:137-145

Guinel FC (2009) Getting around the legume nodule: I. The structure of the peripheral zone in four nodule types. Botany 87:1117-1138

Hartmann K, Peiter E, Koch K, Schubert S, Schreiber L (2002) Chemical composition and ultrastructure of broad bean (Vicia $f a b a$ L.) nodule endodermis in comparison to the root endodermis. Planta 215:14-25

Hirsch AM (1992) Developmental biology of legume nodulation. New Phytol 122:211-237

Hunt S, Layzell DB (1993) Gas exchange of legume nodules and the regulation of nitrogenase activity. Annu Rev Plant Physiol Plant Mol Biol 44:483-511
Iannetta PPM, De Lorenzo C, James EK, Fernandez-Pascual M, Sprent JI, Lucas MM, Witty JF, De Felipe MR, Minchin FR (1993) Oxygen diffusion in lupin nodules 1. Visualisation of diffusion barrier operation. J Exp Bot 44:1461-1467

James EK, Sprent JI, Minchin FR, Brewin NJ (1991) Intercellular location of glycoprotein in soybean nodules: effect of altered rhizosphere oxygen concentration. Plant Cell Environ 14:467474

James EK, Minchin FR, Iannetta PP, Sprent JI (1997) Temporal relationships between nitrogenase and intercellular glycoprotein in developing white lupin nodules. Ann Bot 79:493-503

Karnovsky MJ (1965) A formaldehyde-glutaraldehyde fixative of osmolality for use in electron microscopy. J Cell Biology 25:137A

Kramer EM, Frazer NL, Baskin TI (2007) Measurement of diffusion within the cell wall in living roots of Arabidopsis thaliana. J Exp Bot 58:3005-3015

Laemmli UK (1970) Cleavage of structural proteins during the assembly of the head of bacteriophage T4. Nature 227:680-685

Masepohl B, Witty JF, Riedel KU, Klipp W, Pühler A (1993) Rhizobium meliloti mutants defective in symbiotic nitrogen fixation affect the oxygen gradient in alfalfa (Medicago sativa) root nodules. J Exp Bot 44:419-426

Minchin FR (1997) Regulation of oxygen diffusion in legume nodules. Soil Biol Biochem 29:881-888

Minchin FR, Ianetta PPM, Fernandez-Pascual M, de Felipe C, Witty JF, Sprent JI (1992) A new procedure for calculation of oxygen diffusion resistance in legume nodules from flow-through gas analysis data. Ann Bot 70:283-289

Nap JP, Bisseling T (1990) Development biology of a plant prokaryote symbiosis: the legume root nodule. Science 250:948-954

Newcomb EH, Kaneko Y, VandenBosch KA (1989) Specialization of the inner cortex for ureide production in soybean root nodules. Protoplasma 150:150-159

Oparka KJ (1991) Uptake and compartmentation of fluorescent probes by plant cells. J Exp Bot 42:565-579

Ott T, Joost T, van Dongen JT, Günther C, Krusell L, Desbrosses G, Vigeolas H, Bock V, Czechowski T, Geigenberger P, Udvardi MK (2005) Symbiotic leghemoglobins are crucial for nitrogen fixation in legume root nodules but not for general plant growth and development. Curr Biol 15:531-535

Pauly M, Qin Q, Greene H, Albersheim P, Darvill A, York WS (2001) Changes in the structure of xyloglucan during cell elongation. Planta 212:842-850

Purcell LC, Sinclair TR (1994) An osmotic hypothesis for the regulation of oxygen permeability in soybean nodules. Plant Cell Environ 17:837-843

Raven JA (1987) The role of vacuoles. New Phytol 106:357-422

Sambrook J, Fritsch EF, Maniatis T (1989) Molecular cloning: a laboratory manual, 2nd edn. Cold Spring Harbor Laboratory Press, New York

Serraj R, Fleurat-Lessard P, Jaillard B, Drevon JJ (1995) Structural changes in the inner-cortex cells of soybean root nodules are induced by short-term exposure to high salt or oxygen concentration. Plant Cell Environ 18:455-462

Sheehy JE, Thornley JHM (1998) Oxygen, the NifA gene, nodule structure and the initiation of nitrogen fixation. Ann Bot 61:605609

Streeter JG (1992) Analysis of apoplastic solutes in the cortex of soybean nodules. Plant Physiol 85:768-773

Tjepkema JD, Yocum CS (1974) Measurement of oxygen partial pressure within soybean nodules by oxygen microelectrode. Planta 119:351-360

Van Cauwenberghe OR, Hunt S, Newcomb W, Canny MJ, Layzell DB (1994) Evidence that short-term regulation of nodule permeability does not occur in the inner cortex. Physiol Plant 91:477-487 
VandenBosch KA, Bradley DJ, Knox JP, Peratto S, Butcher GW, Brewin NJ (1989) Common components of the infection thread matrix and the intercellular space identified by immunocytochemical analysis of pea nodules and uninfected roots. EMBO J $8: 335-342$

VandenBosch KA, Rodgers LR, Sherrier DJ, Kishinevsky B (1994) A peanut nodule lectin in infected cells and in vacuoles and the extracellular matrix of nodule parenchyma. Plant Physiol 104:327-337

Vasse J, de Billy F, Camut S, Truchet G (1990) Correlation between ultrastructural differentiation of bacteroids and nitrogen fixation in alfalfa nodules. J Bacteriol 172:4295-4306

Walsh KB (1995) Physiology of the legume nodule and its response to stress. Soil Biol Biochem 27:637-655

Wei H, Layzell DB (2006) Adenylate-coupled ion movement. A mechanism for the control of nodule permeability to $\mathrm{O}_{2}$ diffusion. Plant Physiol 141:280-287
Weisbach C, Walther P, Hartwig UA, Nosberger J (1999) Electron microscopic investigation of water occlusions in intercellular spaces in the inner cortex of lucerne nodules. J Struct Biol 126:59-71

Wittenberg JB, Bergersen FJ, Appleby CA, Turner GL (1974) Facilitated oxygen diffusion: the role of leghemoglobin in nitrogen fixation by bacteroids isolated from soybean root nodules. J Biol Chem 249:4057-4066

Witty JF, Skøt L, Revsbech NP (1987) Direct evidence for changes in the resistance of legume root nodules to $\mathrm{O}_{2}$ diffusion. J Exp Bot 38:1129-1140

Wu S-C, Blumer JM, Darvill AG, Albersheim P (1996) Characterization of endo- $\beta$-1,4-glucanase gene induced by auxin in elongating pea epicotyls. Plant Physiol 110:163-170

Zhong R, Ripperger A, Ye Z-H (2000) Ectopic deposition of lignin in the pith of stems of two Arabidopsis mutants. Plant Physiol 123:59-69 